Mavi Atlas, 9(2)2021: 1-22

Makale Geliş | Received: 06.07.2021

Makale Kabul | Accepted: 24.08.2021

DOI: 10.18795 /gumusmaviatlas. 963418

Araştırma Makalesi | Research Article

\begin{abstract}
Ruken KARADUMAN
Dr. Öğr. Üyesi |Assist. Prof. Dr

Bayburt Üniversitesi, İnsan ve Toplum Bilimleri Fakültesi, Türk Dili ve Edebiyatı Bölümü, Bayburt-TÜRKIYY Bayburt University, Faculty of Humanities and Social Science, Departmant of Turkish Language and Literature,

Bayburt-TURKEY

ORCID: 0000-0003-3059-9424

rukenkaraduman@bayburt.edu.tr
\end{abstract}

\title{
Süheyl ü Nevbahâr'ın Kurgu Dünyası: Yapısal Unsurlar Yönüyle Bir İnceleme
}

\section{$\ddot{O} z$}

Klasik Türk edebiyatı nazım şekillerinden olan mesneviler, yapısal unsurları ve kullanılan anlatım teknikleri gibi hususlarda günümüz hikâye ve romanları ile koşut bir yapı arz eder. Bu bağlamda, mesnevilerin modern anlatı formlarının inceleme yöntemleri ile çözümlenmesi, metne çok yönlü bir bakış açısı kazandırmaktadır. Çalışmamızda Süheyl ü Nevbahâr mesnevisi, roman ve hikâye inceleme yöntemlerinden yola çıkılarak olay, kahramanlar, zaman, mekân, bakış açısı, dil ve anlatım hususiyetleri çerçevesinde ele alınmaktadır. Adı ve müellifi tespit edilememiş Farsça bir eserden hareketle Türkçeye aktarılan Süheyl ü Nevbahâr, 5703 beyitten oluşur. Telif bir aşk mesnevisi olan eserin ilk bin beyti İzzeddin Ahmet, kalan bölümleri ise Hoca Mesud tarafından kaleme alınır. Süheyl ü Nevbahâr, anlatım teknikleri açısından oldukça başarılıdır. Eserde tasvir, diyalog, iç monolog, özetleme gibi daha çok romanlarda görülen teknikler yoğun ve etkili biçimde kullanılmıştır. İçeriği ve çok katmanlı yapısıyla da modern anlatı metinlerinin kurgusunu çağrıştıran bu mesnevi, Süheyl ile Nevbahâr'ın aşklarını ve kavuşma mücadelelerini konu edinir. Zengin bir şahıs kadrosu, mekân ve zamana dair anlatım hususiyetleri konuyu oldukça dikkat çekici kılar. Ancak; beşeri aşk konusunda Anadolu sahasında yazılmış ilk mesnevi örneklerinden olması hasebiyle Süheyl ü Nevbahâr'da kurgusal yönden bazı eksiklikler de mevcuttur. Tekrarlar ve yoğun tesadüflerle örülü olay zinciri, müellifin sıklıkla konuyu kesip okura kendi dünya görüşünü ve yorumlarını aktarması, olaylar sonuçlandıktan sonra da anlatımların didaktik bir amaç çerçevesinde oldukça uzun tutulması vb. eserin kurgusal yönden zayıf tarafları olarak ifade edilebilir.

Anahtar sözcükler: Süheyl ü Nevbahâr, mesnevi, yapısal unsurlar.

\section{Suheyl ü Nevbahar's World of Fiction: Analysis of Structural Elements}

\section{Abstract}

Mesnevi, which is one of the verse forms of classical Turkish literature, presents a parallel structure with today's stories and novels in terms of its structural elements and narrative techniques used. In this context, the analysis of modern narrative forms of mesnevi with analysis methods gives the text a versatile perspective. In our study, Suheyl ü Nevbahâr mesnevi is discussed within the framework of event, heroes, time, space, perspective, language and narrative characteristics based on novel and story analysis methods. Suheyl ü Nevbahâr, whose name and author were transferred to Turkish from an unidentified Persian work, consists of 5703 verses. The first thousand couplets of the work, which is a compilation love mesnevi, were written by Izzeddin Ahmet and the remaining parts were written by Hoca Mesud. Suheyl ü Nevbahâr is very successful in terms of narrative techniques. The techniques seen in modern narratives such as depiction, dialogue, internal monologue and summarizing were used intensively and effectively in the work. Evoking the fiction of modern narrative texts with its content and multilayered structure, this mesnevi is about the love and struggles of union Suheyl and Nevbahâr. A rich cast of characters, narrative features of space and time make the subject quite remarkable. However, Suheyl ü Nevbahâr also has some deficiencies in terms of fiction, since it is one of the first examples of human love written in the Anatolian field. The chain of events processed with repetitions and intense coincidences, the author's frequent interruption of the subject and conveying his own worldview and comments to the reader, keeping the narratives long after the events are concluded within the framework of a didactic purpose, etc. can be expressed as the weak sides of the work in terms of fiction.

Keywords: Suheyl ü Nevbahâr, mesnevi, structural elements. 


\section{Giriş}

XIV. yüzyılın ikinci yarısında Hoca Mesud ve yeğeni İzzeddin Ahmed tarafindan Türkçeye aktarılan Süheyl ü Nevbahâr, çift kahramanlı bir aşk mesnevisidir. Farsça orijinali bulunamayan eserin adı ve ilk kim tarafindan yazıldığ da tespit edilememiştir. Hoca Mesud, eserin Sebeb-i Nazm-1 Tercemân-1 Kitab bölümünde herkesin okuyup anlayabilmesi için yeğeninin elinde gördüğü bu kitabı Türkçeye aktardığını ve ilk bin beytinin yeğeni tarafindan çevrildiğini belirtir. Hatm Şüden-i Kitab ve Özr bölümünde ise tercümeye yaptığ1 eklemelerden söz eder. Bu yönüyle kısmen çift yazarlı, telif bir eser hâline gelen Süheyl ü Nevbahâr'ın İranlı Hâcû-y1 Kırmanî'nin hamsesi içerisinde yer alan Hümâ ve Hümâyun adlı eserden ilhamla yazılmış olabileceği düşünülmektedir. Ancak her iki eserde beşeri aşk konusu işlemesine ve vezinleri aynı (fa'ûlün \fa'ûlün \fa'ûlün \fa'ûl) olmasina rağmen aslında eserler arasında önemli farkliliklar mevcuttur. Bu sebeple, Süheyl ü Nevbahâr'ın aslının Hümâ vü Hümâyun olduğunu söylemek güçtür (Tosunluoğlu \& Melanlıŏlu, 2005, s. 190)

İranlı şair Sâdî̀nin Bostan adlı kitabından seçilen şiirlerin Türkçeye tercümelerini de ihtiva eden Süheyl ü Nevbahâr'ın bu eklemelerle beyit sayısı bazı nüshalarında 5568, bazılarında ise 5703'e ulaşır (Dilçin, 1991, s. 54). Hoca Mesud, hatime bölümünde eserin yazıllıs tarihinin 751; adının ise Kenzü’l Bedâŷ (esssiz güzellikler hazinesi) olduğunu; ancak Süheyl ü Nevbabâr takma adının da kullanılabileceğini söylemektedir. Süheyl ü Nevbahâr, diğer aşk konulu mesnevilere benzemekle birlikte âşıkların kavuşmasının ardından devam eden olaylar yönüyle onlardan ayrılır.

Beşeri aşk konusunda yazılan ilk mesnevi olması ve dil hususiyetleriyle ön plana çıkan Süheyl ü Nevbahâr'ın yorum ve ögüt içerikli didaktik yönü dikkat çekmektedir. Hoca Mesud, hatime bölümünde bu durumu, yaşının ileriki evrelerinde olması ve doğru yolda olmak istemesiyle izah eder. Yine bu bölümde müellif, hikâyenin özünü ve manasını koruyarak çeviri yapmanın yeni bir eser yazmaktan daha zor olduğunu, Türk dilini vezne uydurmanın güçlüklerini, dilin sınırlılıklarını ve insanın istediklerini sadece Türkçeyle anlatmasının kolay bir iş olmadığını da vurgulamaktadır.

\section{Süheyl ü Nevbahâr'daki Yapısal Unsurların İncelenmesi}

Mesnevi ile romanlar, şahısların başından geçen olay veya olaylar etrafinda şekillenen kurgusal birer metin olmaları yönüyle paralellik arz etmektedir. Mesneviler vezin, kafiye ve misra düzeni ile şiir; olay ve buna bağlı yapısal unsurlarıyla roman veya hikâye görünümündedir. Namık Kemal'e göre roman, Hintliler, İbranîler, Yunanlar, Romalılar, Acemler, Araplar, Avrupalılar velhasıl tüm milletlerin her dönemde edebiyatlarında olmuştur. Dolayısıyla roman yeni bir tür değildir. Ona göre, Binbir Gece Masalları'ndan, Leyla ile Mecnun'a, Hüsn ü Aşkk’a pek çok eser, bizdeki ilk romanlar olarak kabul edilebilir (Y1lmaz, 1997, s. 50). Ancak modern anlatı türü olan romanlarla mesnevilerin aralarındaki şekilsel farkın da ötesinde kültürel alt yapıları, bakış açıları, felsefî temelleri, anlayışlanı, yöntemleri ve amaçları gibi birçok yönden net çizgilerle ayrıldığını belirtmek gerekir. Dolayısıyla mesnevi, roman değildir; ancak mesnevilere roman inceleme teknikleriyle yaklaşılması, eserlere dair yeni bir perspektif kazandırabilmektedir.

Müellifin kurduğu sistemi çözmek, vermek istediği mesaj1 nasıl işlediğini görmek ve tasarladığ1 dünyanın öğelerini tahlil etmek noktasında eserin yapısal çerçevesini çizmek önem arz eder. Tahkiye esasına dayalı eserlerin incelenmesi ve müellifin kurgu tekniğinin açılımlanması için metni bütünsel olarak ele alıp anlam tabakalarının yapısını tetkik etmek gerekir. Stevick, yapıyı “öz, hikâye, görünen olaylar dizisi, eserdeki formül, iskelet, mekânizma düzenleme" şeklinde ifade eder ve yapının hikâyenin varlık sebebi, temanın özü olabileceği gibi bir oyundan da ibaret olabileceğini belirtir. $\mathrm{O}$; yapısal incelemeleri, eserin bütününü, kendine has girift yapısını ve gücünü ortaya koyduğu zamanlarda faydalı bir eleştiri kategorisi olarak kabul eder. Stevick'e 
(2004) göre, yapısal tahlillerde eserin biçim özellikleriyle başlanıp müellifin olayları geliştirmesi, düşünce unsurunu işleyişi, kişilerin karakterlerini aşama aşama geliştirmesi, dil ve imajları ele alış1, bakış açısının eseri ne ölçüde zenginleştirdiği ele alınmalıdır (p. 131-136).

Bu çalışmada Süheyl ü Nevbahâr, roman inceleme yöntemleri bağlamında yapısal bir değerlendirmeye tabi tutulmaktadır. Alıntılanan beyitlerdeki numaralandırma ise, Cem Dilçin tarafindan hazırlanan Sübeyl ü Nev-bahâr Inceleme-Metin-Sözlük adlı eser esas alınarak yapılmıştır.

\section{Olay}

Tahkiye esasına dayalı metinlerde asıl unsur vaka/olaydır. Eserde, başlangıç ve sonuç arasında sunulan anlatım halkaları bir yönüyle birbirine ve asıl olaya bağlanır. Vaka belli belirsiz bir hazırlık devresinin ardından zaman akışının bir noktasında başlar, devam eder, bu süre içinde başka olaylarla iç içe geçer ve yeni olaylara zemin hazırlayarak son bulur. Edebi eserlerdeki itibari vaka, dış dünyayı model aldığından temel varlık özelliklerini de esas almak zorundadır (Aktaş, 2005, s. 49-51).

Süheyl ü Nevbahâr'daki olay örgüsü şöyledir:

Yemen'de Bahr adında ulu, adaletli ve akıllı bir sultan vardır. Halkı tarafindan oldukça sevilen bu sultanın kırk eşi olmasına rağmen eşlerinin hiçbirinden çocuğu olmaz. Taht ve servetini bırakabileceği kimse bulunmadığ1 için oldukça üzülen ve endişelenen sultan, halka hazineler dağıtıp iyilikler yapar. Sonunda halkın duaları kabul olur ve Süheyl adı verilen bir şehzade dünyaya gelir. Süheyl, birçok konuda eğitim alıp kendini ispat ettikten sonra tahta çıkar.

Ülkenin ve tüm hazinelerin sahibi olan Süheyl, bir gün babasının kendisinden hazine odalarından birinin anahtarını gizlediğini fark eder. Odayı merak eder ve gizlice aldığı anahtar ile oraya girdiğinde büyüleyici bir bahçe ile karşılaşır. Bu bahçede bir süre sonra karşısına bir havuz ve o havuza yansıyan eşsiz güzellikteki bir kızın resmi çıkar. Süheyl, görür görmez bu kıza âşık olur; kendinden geçer; yemeden içmeden kesilir. Resmin kime ait olduğunu araştırırken sarayda görevli, birçok ülkeyi gezmiş olan Nakkaş, gördüğü kızın Çin hükümdarının kızı olduğunu söyler. Onu bulmak üzere ikisi, bir orduyla birlikte yola çıkar. Yolculuk esnasında insanları cömertliği ile etkilemek isteyen Süheyl, her firsatta ziyafetler düzenler; halka ve şahlara hediyeler dağıtır. Nihayet Çin'e ulaştı̆̆ında da sultanı ve halkı yine düzenlediği davetler ve cömertliğiyle kendine hayran birakır.

Bir süre sonra Çin hükümdarı, güvenini ve sevgisini kazanan Süheyl’in ülkede kalması için yakınlarında saray kurdurma isteğine rıza gösterir. Nevbahâr'ın köşküne yakın bir yerde on gün gibi kısa bir sürede ihtişamlı bir saray inşa ettiren Süheyl, sarayın bahçesine de onun yansımasının görülebileceği bir havuz yaptırır. Süheyl, böylece her gece Nevbahâr'1 görme firsatı elde eder. Nevbahâr da Süheyl'i görüp ona âşık olmuştur. Bir gün dadısını gönderip Süheyl'i köşküne davet eder. Böylece her gece görüşmeye başlayan âşıklar, yakalanmamak için tünel kazıp yerin altında oda yapmaya karar verir. Bu şekilde birliktelikleri mutlu bir şekilde sürerken Süheyl, ailesini özlemeye başlar ve onları görmek üzere memleketine dönmek ister. Ancak Çin hükümdarı, bu isteğinin hemen mümkün olamayacağını söyleyip Çin'den ayrılmasına izin vermez. Nevbahâr da Süheyl ile Yemen'e kaçmak üzere bir plan yapar. Bir akşam hizmetçi kıllı̆ına girerek babasını ve ağabeylerini sarhoş eder ve Süheyl'e, kendisini şehir dışında beklemesini söyleyerek saraydan ayrilır.

Süheyl, sözleştikleri yerde Nevbahâr'ı beklerken yorgunluktan uyuyakalır. Bu esnada şehri dolaşan Saluk adlı bir haydut, Süheyl'i görür. Onu öldürmeye kıyamaz; ancak atlarını ve tüm eşyasını alır. Saraydan kaçıp sözleşilen yere gelen Nevbahâr ise karanlıkta Saluk'u Süheyl zanneder. Hızla onun yanındaki ata biner ve Saluk'la birlikte yola çıkar. Sabah gün ağardığında yanındaki kişinin Süheyl olmadığını fark eden Nevbahâr, bir kurnazlık düşünür. Saluk’a kendisine âşık 
olduğu için onunla isteyerek geldiğini söyler ve bir şekilde Süheyl'in olduğu yere geri dönmesi için onu ikna eder.

Bunlar olurken Nakkaş, askerleri de alıp Çin'den uzaklaşmaya karar verir. Çin fağfuru ise, sabah olduğunda Yemen kavminin şehirden ayrıldığını ve Nevbahâr'ın da odasında olmadığını görüp onları aramaya çıkmıştır. Bir süre sonra fağfurun ordusu ile Nakkaş'ın ordusu karşı karşıya gelir. Aralarında bir savaş başlar. Nakkaş yenilip esir düşer ve tüm olanları Çin hükümdarına anlatmak durumunda kalır. Durumu öğrenen fağfur, Nakkaş’ı serbest bırakır ve o da Süheyl’i aramak için yeniden yola koyulur.

Nevbahâr, bu esnada kaçıp Saluk'tan kurtulmuştur. Ancak; çöl, orman gibi daha önce hiç bilmediği yerlerde günlerce yalnız başına yol alırken büyük bir korku ve pişmanlık içindedir. Bir süre sonra bir deniz kıyısına gelir. Burada gördüğü geminin sahibi olan Cühûd'a yüzünü gizleyerek Çin hükümdarının oğlu olduğunu söyler ve onun gemisine biner. Cühûd, babasina götürmek için Nevbahâr'ı yanına alır. Bir aylık gemi yolculuğunun ardından Kusta şehrine varırlar. Şehrin Talis adlı bir hükümdarı vardır. Bu hükümdarın oğlu Kaytas da tesadüfen gördüğü Nevbahâr’a âşı olur. Kaytas, Cühûd'dan altın ve misk karşıllğında kızı almak ister. Ancak Nevbahâr, Cühûd'u ona âşık olduğuna inandırıp Kusta'dan birlikte kaçmaya ikna eder. Cühûd, yolculuk sırasında Nevbahâr'a yaklaşmaya çalışı; ancak Nevbahâr, çeşitli oyunlarla onu karaya çıkana kadar oyalamayı başarır. Karaya çıktığında ise Cühûd'u atlatıp atıyla tekrar yola çıkar.

Nevbahâr, günler sonra yine bir deniz kıyısına gelir. Burada denizden çıan cinlerle ve genç, güzel bir kızla karşılaşıp ona kendi hikâyesini anlatır. Peri padişahının oğlu tarafından kaçırılan bu kız, Nevbahâr için oldukça üzülür ve mücevherler hediye ederek Tûfân şehrine giden yolu gösterir. Nevbahâr, oradan ayrılıp Tûfân'a ulaşır. Bu şehrin halkı, hükümdarları öldükten sonra tahta kimin çıkacağını bir türlü belirleyemeyince yolda ilk karşılaşacakları kişiyi hükümdar yapmaya karar vermiştir. Böylece oraya ilk gelen kişi olarak Nevbahâr, şehri yönetmeye başlar. Süheyl'i bulmak için de şehrin girişindeki kubbelerin altına birer havuz yaptırır. Bu havuzlara yansıması düşecek şekilde kendi resmini çizdiren Nevbahâr, orada bulunan askerleri bu resmi görüp ağlayan ve bayılan kişileri saraya getirmekle görevlendirilir.

Saluk, Nevbahâr'dan ayrıldıktan sonra Süheyl'i bulamayıp tekrar Nevbahâr'ın yanına dönmek ister. Ancak; ayrıldıkları yerde kendisini beklemediğini fark edince Nevbahâr'ı bulma ümidiyle günlerce dolaşıp sonunda da harap ve bitap şekilde Tûfân’a ulaşır. Şehrin girişindeki havuzda Nevbahâr'ın resmini görüp bayıldığından saraya götürülür. Nevbahâr'ın emri ile zindana atılır. Diğer taraftan Kaytas, yine Nevbahâr'ı bulmak için ülkesinden ayrılmış ve yolda daha önce Nevbahâr'ın görüp yardım aldığı kız kardeşi ile karşılaşmıştır. Kaytas'ın kardeşi, olanları öğrenince Kaytas'1 yolundan vazgeçirmek için ona hazineler teklif eder, anne ve babasının üzüntülerini anlatıp birlikte ülkelerine dönmeyi önerir. Ancak Kaytas, Nevbahâr'ı görme arzusundan vazgeçmez. Sonunda bir periyle bulutların üstünden uçarak Tûfân şehrine ulaşır. Cühûd ise Nevbahâr'ı bulmak için gemisinden uzaklaşıp günlerce ormanlarda gezer, aslanlarla mücadele edip çöllerde dolaştıktan sonra Tûfân'a gelir. Burada o da Nevbahâr'ın havuza yansıyan resmini görüp bayılınca Nevbahâr'ın huzuruna götürülüp sarayda misafir edilir.

Saluk, Kaytas ve Cühûd'un ardından Süheyl'in macerası Nevbahâr'ı beklerken uyuyakaldığ1 andan itibaren şöyle anlatılır: Süheyl, sabah uyanınca atların gittiğini görüp Nevbahâr'ı aramaya çıkar. Sonunda bir kaleye ulaşır. Kalenin sahibi olan Calus'la içki içip sohbet eder ve kısa zamanda arkadaş olur. Calus, Süheyl'in hikâyesini duyunca ona yardım edeceğine dair söz verir. Çin ülkesinin aslında kendi babasına ait olduğunu ve bir hile ile alındığını anlatır. Daha sonra da Nevbahâr'ın yerini öğrenmek için Çin'e casus göndermeye karar verir. Gönderilen casus ise kısa bir zamanda, Nevbahâr'ın orada olmadığını öğrenerek durumu onlara belirtir.

Aradan bir süre geçer. Calus'la yoldan geçen Heveranlı kervanlardan biri arasında savaş başlar. Süheyl, Calus'un askerleriyle birlikte büyük bir mücadele vermesine rağmen, pusu kuran 
düşmanlar tarafindan esir edilir. Haveran hükümdarının huzuruna çıkarılır. Hükümdar, Süheyl’in önemli biri olduğunu hemen anlar. Hükümdarın askerleri de gücünü ve cesaretini övdükleri şehzadeye zarar verilmemesini istemektedir. Şah, Süheyl'i takdir eder; birlikte ava çıkar; onunla dostluk kurar. Bu esnada Süheyl, bir tesadüf sonucu Nakkaş'la karşılaşır. Nakkaş, başından geçenleri anlatır ve birlikte Nevbahâr'ı aramaya çıkarlar. Yolları zulmeden ve cimri bir padişahın ülkesi olan Yun'a düşer. Nakkaş ve Süheyl burada zindana atılır. Süheyl, zindandaki muhafizı ikna ederek onun yardımları ile kaçar. Nakkaş'la birlikte Nevbahâr'ın olduğu şehre gelir. Süheyl de burada Nevbahâr'ın resmini görünce bayılır. Nakkaş'la ikisi Nevbahâr'ın huzuruna çıkarılır. Öncelikle Nakkaş’tan tüm olup biteni öğrenen Nevbahâr, herkesi bir meydana toplar. Bu meydana üç taht kurulmasını emreder. O tahtlara Süheyl, Nevbahâr ve Kaytas oturur. Cühûd ve Saluk da meydana getirilir; burada sorgulanıp suçlarını itiraf ettikten sonra Nevbahâr'a dokunmadıklarını anlatırlar. Sonra da Kaytas'a ve Süheyl'e başlarından geçenler sorulur. Tüm macerasını ve içinde bulunduğu hâli anlatarak oradaki halkı etkileyen Süheyl'in ardından Nevbahâr, kendi hikâyesini bir başka kişi üzerinden dile getirir. Halktan, bu kız bin yiğitten yeğdir, nidaları yükselmeye başlar. Nevbahâr, daha sonra kimliğini açıklar ve tahta Süheyl’in çıkması gerektiğini söyler. Süheyl'in tahta çıkmasının ardından Saluk ve Yun şehrinin hükümdarı boyunları kesilerek Cühûd da ağaca bağlanıp kamçılanarak cezalandırılırken Kaytas'a ve Süheyl'e yardım eden zindancıya ise çeşitli hediyeler verilir. Nakkaş, vezir yapılır ve Süheyl'le Nevbahâr nihayet evlenirler.

Düğünün ardından Süheyl'e birçok iyiliği dokunan Calus'a teşekkür için; Çin fağfuruna da af dilemek üzere birer mektup gönderilir. Bir süre sonra Nevbahâr, Hümam adlı bir şehzade dünyaya getirir. Oldukça cesur, güçlü ve maharetli olan bu şehzadeye büyüdüğünde tahtı birakan Süheyl, babasının isteği üzerine Yemen'e döner. Burada Hilal adlı bir erkek çocukları daha olur. Yemen sultanı, daha sonra hastalanarak öldüğünde Süheyl, ülkeyi yönetmeye devam eder.

Sürekli bir hareket ve değişimin hâkim olduğu Süheyl ü Nevbahâr'da girift bir olay kurgusu mevcuttur. Eserde her kahramanın ayr1 ayrı anlatıldığı olaylar bir süre sonra tek noktada birbirine ulanmaktadır. Mesnevide, çerçeve öykü ile kuşatılan iç öyküler, ortak izlek etrafında birleşirken masallardaki gibi bir anlatım kurgusu dikkat çeker. Örneğin; ayrı yollara giden kahramanların yollarının tek mekânda kesişmesi masallarda tekrar eden bir motiftir. Yine kırk eşi olan Bahr'ın hazineleri ve çeşitli özellikleri ile takdimi masalsı bir atmosferin başlangıçtaki habercisi olmaktadir.

Süheyl ü Nevbahâr mesnevisinde, masallardaki klasik kurguya paralel olarak iyilerin ödüllendirilip kötülerin cezalandırılması, tesadüflerin doğallık sınırlarını aştığı durumlar, olağanüstü unsurların doğal olarak aniden olaya dâhil olması gibi hususlara rağmen oldukça realist anlatımlar da karşımıza çıkar. Örneğin; Nevbahâr'ın saraydan kaçmak için kılık değiştirmesi esnasinda yaşananlar veya yine onun Cühûd'dan kurtulmak için verdiği mücadele, çöldeki maceralarına dair sahneler oldukça akıcı ve inandırıcı bir biçimde işlenmektedir. Okur, bu anlarda heyecan içinde başarıyla düğümlenen gerçekçi olayların ve oyunların içine çekilir.

Süheyl ü Nevbahâr'da olay, sık sık didaktik anlatımlarla kesintiye uğrar. Özellikle mesnevinin bittiği noktada Süheyl'in babası tarafindan verilen öğütler oldukça uzun tutulmuştur. Müellifin, tüm ideallerini aktarmaya çalıştığı bu bölümler, metnin kurmaca olduğunun sıklıkla anımsanmasına neden olur. Eserin olay kurgusundaki bir başka aksaklık ise, çatışmayı oluşturacak karşıt güçler kurgulanırken Nevbahâr'ın babası ve kardeşlerinin neden tercih edildiğinin gerekçelendirilmemiş olmasıdır. Nevbahâr'ın babası, Süheyl ile kızını evlendirme konusunda herhangi bir olumsuz tavır içinde değildir. Yine de Nevbahâr ve Süheyl kaçmaya karar verir. Dolayısıyla sonradan uzun süreli bir ayrilığın müsebbibi olacak kötü bir karakter olarak seçilen babanın entrik kimliği önceki anlatımlarla örtüştürülemez. Süheyl’i oldukça seven, onun için davetler düzenleyen, hiçbir arzusunu geri çevirmeyen sultan, vuslat noktasında bir engel 
oluşturmamasına rağmen, müellifin böyle bir tasarrufta bulunmasının sebebi anlaşılamayan bir husus olarak belirir. Kötü karakterler inşa etme hususunda zayıf olan eserde daha sonra fağfurun dilinden bu durum şöyle ifade edilir:

Eger ol kadar biledüm ki Süheyl

Benüm kızuma eylemiş idi meyl

Dökince vü saçınca çok mâlını

Bana azacuk kendü ahvalini

Dise nite dek duradum dinedüm

An1 hoz güyegü ben idinedüm (2800-2801-2802)

Ne lâzım ki kaçar yabana düşer

Gelüp kızumı alsun hem eyle düşer (2818)

Mesnevideki açıklanamayan, tutarsız anlatımlardan bir diğeri Yemen sultanı Bahr’ın, oğluna Çin hükümdarının kızını aslında rahatlıkla alabilecek şartlara sahip iken Süheyl'in gereksiz bir yolculuğa çıkma konusundaki ısrarıdır. Olay zinciri içerisinde çelişik görünen başka bir husus ise veziri ile Süheyl'in askerlerini görüp telaşlanan ve büyük bir korkuya kapılan Çin fağfurunun aslında çok daha kalabalık ve güçlü bir orduya sahip olduğunun ilerleyen olaylar esnasında anlaşılması olur. Süheyl'in tüm askerlerini bir savaş esnasında alt eden hükümdarın baştaki tavrı ile sonradan yaşananlar, metinde izahı olmayan bir başka kurgusal hatadır. Yine Nevbahâr'ın evden kaçtıktan sonra bir anda usta bir avcının yetenekleriyle donanması, saraydan hiç çıkmamış nazlı bir sultan kızı imajı ile zıtlık oluşturmaktadır. Müellif de aslında bu çelişkinin farkındadır ve onun böyle bir özelliği nasıl olabilir diye kendisinin dahi garipsediği durumu okura sorar. Böylece anlatıdaki mantık hatası müellif tarafından tasdiklenir:

Üzegü gerüp cüst sıgadı kol

Yayı bagrınun içine girdi ol

Degül mi aceb katı yayı çeküp

At üstinde degül ki yirde çöküp (2884-2885)

Müellif, zaman zaman da anlattıklarının mantığını, duygusal arka planını, kahramanın eylemlerini açıklayan itici gücü belirterek yadırgatıcı söylemleri ortadan kaldırmaya çalışır. $\mathrm{O}$, her daim kahramanlarının tarafinı tutar. Dini ve toplumsal açıdan uygun olmayan davranışlarına dahi birer mazeret bulur. Bu tarz eylemlere önce eleştirel bir bakışla yaklaşsa da daha sonra muhakkak olanları mazur gösterme yoluna gider. Kahramanların edimlerini haklı çıkarmak istediğinde de çeşitli örneklerden, teşbih ilgilerinden yararlanır. Bu noktada okurun garipseyeceğini düşündüğü anlatımları ise hemen fark eder:

İki kişi çün cânı atdı oda

Aceblemenüz düzdilerse oda

Dürişse kişi kaygusin yir olur

Yiri yâr içün yaruban yir olur (2001-2002)

Mesnevide, Süheyl ile Nevbahâr'ın ilk karşılaşmalarına kadarki olayların anlatımında olduğu gibi, bazı bölümlerin oldukça uzun tutulduğu görülmektedir. Buralarda yavaşlayan akış ise, merak ve gerilim unsurları ile tekdüzelikten kurtarılır. Gerçekçi mekânlarda yaşanan olağanüstü hadiseler, zaten alelade olmayan bir maceranın temposunu iyice yükseltir. Özellikle gizemli veya fantastik unsurların anlatıldığı bölümlerde heyecan öğeleri ön plana çıkar. Böylelikle okurun ilgisi her daim canlı tutulur. 
Bir anlatıda malzemenin doğal bir bütün hâlinde sunulmaması, anlatının estetiğini olumsuz yönde etkiler. Yadırgatıcı, şaşırtıc1, aykırı gelen bir yap1 metnin inandırıcıllı̆ına da zarar verir. Her metin, ne kadar olağanüstülüklerle bezeli olsa da inandırıcıllı̆̆1 tesis etmeye mecburdur. Zira eserdeki kopuk ve mesnetsiz anlatımlar, okur için özensiz ve anlamsız bir görünüm arz etmektedir. Dolayısıyla müellifin, olayları neden-sonuç ilgisi içinde sunarken anlatımlarını gerçekle örtüştürmesinden ziyade gerçeklik duygusu uyandırması esastır. Bu noktada Süheyl ü Nevbahâr'da, bilhassa olağanüstülüklerin kurgulanışında başarılı veya inandırıcı olunamasa da, hikâyeyi inandırıcı kılan birçok detaya yer verilmesi ile bazı sorunlar kısmen giderilmektedir. Ancak müellif, detaylarda yakaladığı başarıya rağmen periler ve denizden çıkıp bir süre karada gezdikten sonra tekrar denize dönen, erkekli dişili hareket eden, tüylü, yırtıcı hayvanlar gibi bazı olağanüstülüklerin tahayyülünde özgünlükten uzak görünür:

Denizden çıhup geldi bir cânavar

Degül âdem illâ eli ayagı var

Anı vü atı gördi hîç dınmadı

Kuruya çıup agaca binmedi

Elinde tutup bir güher çihdıdı

Gözetdi vü çepçevre key bahdıdı

Kodı güheri anda girdi girü

Denize vü bir yana vardı girü (3425-3428)

Henüz ol dem endişe içindedi

Hemân yirde ol mîşe içindedi

Apansuzda ün geldi vü meşgale

Deniz yüzi oldı tolu meşale

Su balgışdıvü çıkdı hayvân öküş

Kiminün yüzi it kimün başı kuş

Kimisi âdem başlu gövdesi at

Kimi kuş gibi uzadıpdı kanat

Kiminün başı aslan ayagı̂ pîl

Kimisini basmış keçi bigi kıl (3430-3435)

Ancak periler tarafından kaçırılıp denizin altında yaşayan kızın hikâyesi ile alışılagelmiş peri hikâyelerinin dişına çıkılmış, müellifin hayal gücünün zenginliği bir ölçüde hissettirilmiştir:

Ben ü dahı birkaç ulular kızı

Şol ohtın ki uyıdı deniz yüzi

Gemiye girüp gezdüm içdüm yidüm

İrişdi gice vü birez uyıdum

Ki çengün âvâzı dimâgumı ter

İdüpdi perîler ulusı meger

Ol arada hâzır bulınur kapar

Su altına iltür gemiden sapar 
Anı bilürem çünki uyanuram

Su altındayiken oda yanuram (3489-3493)

Süheyl ü Nevbahâr'da yolculuk, eğlence, mücadeleler ve akıl oyunları üzerine şekillenen kurgunun temel izleği aşktır. Ancak cömertlik de aşk kadar ön plana çıkarılan bir başka izlek olarak dikkat çeker. Metnin anlam tabakaları içinde yer yer tekrar eden cömertlik kavramı kırk eşi olmasına rağmen yıllarca çocuğu olmayan hükümdarın çocuk sahibi olması; Süheyl'in halkın, sultanların sonra da Nevbahâr'ın gönlünü kazanması gibi birçok olay üzerinden sıklıkla vurgulanir.

\section{Kahramanlar}

Seçkinin, sıradana/avama nazaran daha dikkat çeken bir figür olduğu, soyluların yaşam biçimlerinden kesitlerin sunulduğu mesnevilerde kahramanlar; genellikle padişah, şehzade, sultan kızları, vezirler ve onların çevresindeki kişilerden oluşur. Süheyl ü Nevbahâr mesnevisinde de olaylar; Yemen ve Çin padişahları, onların çocukları, eşleri, vezir ve diğer yardımcıları arasında geçmektedir. Kahramanların eserlerde soylulardan seçilmesinin nedeni Lukacs'a (2007) göre: "Yazgının ontolojik mecrasını hayatın tüm sıradan nedenselliklerinden arındırma ihtiyacıdır. Çünkü toplumsal olarak başat figürün çatışmaları duyusal açıdan simgesel bir varoluş yanılsamasını sürdürmekle birlikte sadece trajik sorundan kaynaklanıyordur. Çünkü ancak böyle bir figür, dış görünüşünün biçimlerinde bile anlamlı bir yaratılmışlı̆ga uygun bir atmosferle kuşatılabilir.” (p. 74).

Klasik mesnevilerde kişilerin eylemleri, müellifin ve toplumun ideal kahraman algisına göre şekillenir. Beklentileri karşılamak üzere kurgulanan ve gelenekselleşen kahramanlar ise anlayış, duyuş ve eylem ortaklığı ile statik bir yapı ortaya koyar. Sınırları belirlenmiş kişilerin kabul edilebilir, şaşırtmayan tavırları genel bir başkahraman imajı çizer. Bu kahraman bütünsel ve tanıdık bir kimlik olarak merkezi konumdadır ve tüm olumsuzluklardan arındırılmıştır. Olaylar, onların mücadeleleri neticesinde olgunlaşmalarına yönelik kurgulanır. Seçilmiş ve idealize kahraman olarak ön plana genelde erkek kahramanlar çıkartılır. Mesnevilerde ön plana çıarılan bireysel ve somut kahramanlık edimleri, Süheyl ü Nevbahâr'ın başlangıcında Süheyl üzerinden somutlaştırılırken daha sonra müellif, Nevbahâr'ı merkeze almıştır.

Güçlü karakterler ve büyük bir idol tasarısının hâkim olduğu mesnevilerde kahramanlar, büyük zorluklarla karşılaşır. Özellikle başkahramanın olgunlaşma ve aşk1-tahtı hak etme sürecinde bu zorluklarla mücadele oldukça önemlidir. Aldığı kararlarla diğer kahramanların da hikâyelerini biçimlendirmesi, cesaretle bilinmezliklere açılması ile Nevbahâr'ın mücadele-olgunlaşma serüveni, Süheyl'e nazaran mesnevide daha ön plana çıkar.

Evden uzaklaştıktan sonra yaşadığı iç çatışmalar, pişmanlıkları ve karakter dönüşümleri ile Nevbahâr'ın yaşadıkları sürprizlere olabildiğince açıtır. $O$, hiç bilmediği bir dünyada yalnız ve savunmasızdır. Buna rağmen, kendini kötü niyetli insanlara karşı korur; onları çeşitli oyunlarla oyalayarak zarar görmeden her türlü zorluktan kurtulur. Yalan ve hileye de başvuran bu oyunbaz kadın, aklı sayesinde birçok güçlü erkeği alt eder. Çeşitli vesilelerle fiziksel ve ruhsal yönden gücü sık sık sınanırken bu sınavları Süheyl'den daha büyük bir başarı ile verir. Nevbahâr, karşısına çıkan her engelle gelişimine devam eder. Bazen beklenmedik davranışlarda da bulunan Nevbahâr, bu yönleriyle tip değil, bir karakter özelliği gösterir.

Anlatı karakterleri psikolojik yapılarına göre düz ve yuvarlak olmak üzere ikiye ayrılır. Düz karakterler, insan mizacındaki hâkim özellikleri temsil eden tiplerdir ve tek bir fikrin, niteliğin sembolüdür. Hiçbir psikolojik değişim göstermeyen düz karakterin birden fazla niteliğe sahip olmasıyla yuvarlak karakter özelliği ortaya çıkar. Derinliği ve değişimleri ile okura kendi kimliklerine ulaşan düz karakterler, mesajın tek seferde verilebilmesini sağlar. Tanıdık geldiklerinden tekrar takdim edilmeleri ve geliştirilmeleri gerekmez. Kendi atmosferlerini 
beraberlerinde gezdirirler, bellekte kolaylikla kalabilirler. Yuvarlak karakterler ise daha karmaşık bir yapıya sahiptir. Basit ve statik değil çok boyutlu insanlardır. Bizi inandırıcı biçimde şaşırtabilirler (Stevick, 2004, p. 170-174) Süheyl ü Nevbahâr mesnevisinde yuvarlak bir karakter olarak kabul edebileceğimiz Nevbahâr, eserin ilgi merkezidir ve her an şaşırtmaya devam eder.

Nevbahâr'ın değişim süreci diğer kahramanlara nispetle daha somuttur. Eserde karakterin duygu ve düşüncelerindeki, eylemlerindeki dönüşümleri açıkça belirtilir. Zorunlu mücadeleler ve tehlikeli serüvenlerin başında babası ve kardeşlerini aldatan Nevbahâr; plancı, hile yapan, rahatça yalan söyleyebilen bir kahramandır. Evden uzaklaştığında karşısına çıan ilk engelle pişmanlık duyar, geri dönmek ister. Ancak sonradan tavrı ve kissiliği Tûfân şehrinin sultanı olmasına kadarki süreçte aşama aşama değişir. Nevbahâr, hiçbir zaman donuk olmayan, capcanlı bir karakter olarak içinde kopan firtınaları her an hissettirir:

İçümde yanan cışk odı çün baş götürdi

Başuma kaza gör ne ser-encâm getürdi

Anca çabaladum ki sataşdum bu belâya

Ne bahtlu kim ussiylla epsem oturdı

Râhat balınun nûşına barmah banamadum

Zahmet arusı nîşteri bagruma baturdı

Tedbîr ü çevüklik ile iş bitürimedüm

Takdîr irişüp hey dimedin gör ne bitürdi

Nâz ile nâzük bisledügüm ten döşene taş

Ol kanı ki yumşak döşek içinde yaturdı (2488-2492)

Eserin bir diğer başkahramanı Süheyl'in macerası, merak ettiği keşfedilmemiş büyülü bir dünyanın kapılarını açma isteği ile başlar. Bu kapıların ardında, yıllarca babası tarafından uzak tutulmak istendiği büyük bir aşk hikâyesi onu beklemektedir. Ancak Süheyl'in, diğger mesnevi kahramanlarının aksine, bu hikâyede büyük zorluklarla mücadele etmesi gerekmez. Nevbahâr'ın ülkesine giderken yanında binlerce askeri ve bilge bir yardımcısı vardır. Tehlikelere atılmadan hükümdarların ve halkın dostluğu, sevgisi ile yolculuğunu tamamlar. Süheyl, oldukça korunaklı bir alanda güvenle ilerlerken şanslı tesadüfler ve yardımcıların desteği onun zorlanmadan vuslata ermesini sağlar. Tekâmül sürecini tamamlayıp tahta çıktığında ise; akıllı, barışçı temkinli birine dönüşmüştür. Ancak bu gelişim sürecinin aşamaları okura tam olarak aktarılmaz. $O$, kendiliğinden veya doğuştan ideal bir kimlik olarak var olmuş gibidir.

Bedensel ve ruhsal özellikleri ile de diğer mesnevi kahramanlarını andıran Süheyl; sakin, mütevazı, uyumlu bir yapıya sahiptir. Meraklı ve dikkatlidir. Babasının kapalı tuttuğu kapının ardındaki sırlara ve gizeme çekildiğinde dahi bu kapının anahtarını elde etmeye çalışırken dengeyi kurar, kontrolü bırakmaz. Yardımcı kahramanın yol gösterme fonksiyonunu zamanı geldiğinde eline alır. En yakınındaki, dostu olan Nakkaş’a bile tüm sırlarını açacak kadar güvenmez, Nevbahâr'la bir araya gelmelerini veya birlikte kaçma planları yaptıklarını saklar. Nakkaş'ın çok sonradan yapılacak sadakat sınavına tabi tutulmasını bekler. Ailesinin duygusal baskılarına karşı koyar, yolundan dönmez. Ancak zamanı geldiğinde onlara karşı sorumluluklanını da yerine getirir.

Süheyl tek boyutlu bir kahraman değildir. $O$, hatalar da yapar. Mesela güven ve dostluğunu tam da kazandığı sırada Nevbahâr'ın babasına ihanet eder. Fağfurun rızasını alabilecek durumdayken sebebi tam olarak anlaşılamayan bir zorluğa atılmak gibi yersiz kararlar alır. Nevbahâr'la kaçışları esnasında düştüğü zafiyetle büyük sorunlara yol açar. Bu sırada Nakkaş’1 ve ordusunu da kaybederek hikâyedeki güçlü kurtarıcı işlevini yitirir. Süheyl, bazen de umulmadık anlarda büyük bir savaşçıya dönüştügüüde dahi bir anda yenik düşmesine neden olan hatalar 
yapar. Yani o, bir kahraman olarak kurgulanırken hem olumlu hem olumsuz cepheleriyle realisttik bir insan tasavvuru içinde sunulur.

Süheyl; tüm beklentileri karşılayan, belirgin kahraman çizgilerine sahip, savaşçı bir karakter değildir. Örneğin; bir mücadele esnasında öne atılıp düşmanları alt edecekken kısa bir süre sonra esir düşer. Nadiren karşımıza çıkan bu kahramanlık sahnelerdeki anlatımların dışında ise, onun cesaret ve gücüne yönelik vurgular oldukça sınırlıdır. Süheyl daha çok cömert, ailesine bağlı, sahip olduğu karakter özellikleri ile vefalı dostlar edinebilmiş bir kahramandır. O; bilgisi, sanattaki mahareti ve kişiliği ile eşsiz biri olarak ifade edilir. Cömert, yakışıklı, güçlü, saygıll, iyi huylu ve adaletlidir.

İç dünyası ve maceraları ayrıntıll biçimde anlatılan ve yuvarlak karakterler diyebileceğimiz bu başkarakterlerin dışında olayların akışı içinde önemli işlevleri olan kahramanlardan biri de Nakkaş’tır. Nakkaş; gözü tok, samimiyetle hizmet arzusunda olan, akıllı, olgun, temkinli biridir. Düz karakter özellikleri göstermesine rağmen bazen geleceği de tahmin edebilen bu kahramanın anlatımları, okurun önceden bilgilendirilmesine neden olur ve şaşırtma özelliği olaydan kahramana aktarılır. Yani; ileri görüşlü ve insan davranışlarını tahmin edebilecek kadar akıllı Nakkaş, zaman zaman olayların ön anlatıcısı olarak öngörüsü ile de şaşırtır:

Süheyl'ün tapusina nakkâş işit

$\mathrm{Ne}$ dir eydür iy devlet issi yigit

Kiyâs eylerem ben ki ol mâh-1 Çîn

Bugün kişi viribiyiser için

Açılasıdur her ne kim râzı var

Bayık bil ü işüne olgil süvâr (1675-1677)

Süheyl ü Nevbahâr mesnevisinde kahramanlarının tipolojisi genel olarak iyi-kötü çatışmasına dayanır. Şahıslar eserde ya iyi ya da kötüdür. Örneğin; Nevbahâr'a gönlünü kaptıran ve onun uğrunda her şeyi geride bırakabilen, sadakatini çeşitli vesilelerle ispatlamış Kaytas, iyiler arasındadır. Saluk ise; insanlara zarar veren bir eşkıya olarak Süheyl veya Nevbahâr'a herhangi bir zarar vermemiş olsa da hikâyenin kötü kahramanları arasında yer alır. Ancak bu düz karakterli şaşırtmayan kahramanlar bazen kararsız ve değişime açık bir kişilik sergiler. Okur, gelgitler yaşayan kahramanın bir sonraki adımını tahmin edemez. Buradaki belirsizlik bir heyecan unsuruna dönüşür. Mesela Nevbahâr'a başta yardım eden, onu koruyan Cühûd sonradan teklif edilen büyük bir hazine karşıllğında Nevbahâr'ı vermeye razı olur. Cühûd çıkarc1, verdiği sözleri tutmayan, paraya düşkün bir kişidir. Ancak o, daha sonra Nevbahâr'ın sözlerine aldanıp kazancını heba eden vefalı, saf bir âşı̆̆a dönüşür. Ondaki değişim süreci ise oldukça doğal ve inandırıcı bir izahla sunulmaktadır. Cuhûd'un bu yapısı çelişki oluşturmaz, her safhası tutarlı bir şekilde işlenir. Eserdeki diğer kişilerin aksine ne iyi ne de kötü bir kahraman olarak sunulmayan Cühûd'un bu bağlamda, iyilerin ödüllendirilip kötülerin cezalandırıldığı eserin sonuç bölümünde önce cezalandırılıp sonra değerli hediyelerle taltif edilmesi dikkat çeker.

Dadı, kadın başkahramanın yanına Süheyl ve Nakkaş'a simetrik olarak yerleştirilmiş merhametli, ileri görüsslü, irfan sahibi bir başka kahraman olarak karşımıza çıkar. Tecrübeleriyle olaylara zemin hazırlar, tamamlayıcı kişilerden biri olur. Eserde hükümdarlar, oğullarının her dediğini yapan, iyi, cömert ve fedakâr baba kimlikleri ile sunulur. Onlar; akıllı, talihli, adaletli, yemeyi içmeyi seven, cömert kimselerdir. Süheyl ü Nevbahâr'da bu kahramanların dışında, olay üzerindeki fonksiyonlarına göre az görünen veya olaya çok az etkisi olan şahıslar da mevcuttur. Çin'e casus olarak gönderilen zenci, onun görüştüğü yaşlı kadın, Süheyl’in Ristetalis adlı veziri hikâyenin fon şahısları olarak yer alır. 


\section{Zaman}

Süheyl ü Nevbahâr mesnevisinde, Yemen padişahının çocuk sahibi olmak istemesi ile ölümü arasındaki zaman diliminde yaşanan olaylar aktarılmaktadır. Mesnevide iki gece iki gündüz, bir ay, on gün, bir hafta, beş altı gün içinde, bir gün, birçok gün, üç gün gibi birtakım zamansal ifadeler kullanılır. Ancak ay, yıl veya mevsimlere dair herhangi bir bilgi verilmez. Süheyl ü Nevbahâr'da belirsiz olan zaman, mekândan daha önemli bir unsur olarak sik sik zikredilir ve teşbih, teşhis gibi çeşitli sanatlarla zamana bir kimlik tahsis edilir. Eserdeki en sanatsal ve hayal gücüyle canlı tasvirlerin sunulduğu bölümler, özellikle gecenin veya sabahın ilk demlerinin anlatıldığı beyitlerdir. Burada dilsel oyunlar ve oldukça orijinal ifadeler dikkat çeker. Gündüz vakti eserde başlangıç imajıyla eşleşir ve beyazlık canlılık ifade eden kavramlarla anlatılır. Sabahın gelişi zencilerin yüzlerini kafur ile yıkamaları, dünyanın samur kürkünü çıkarıp (beyaz) kakum kürkünü giymesi, göğün karakargasının yumurta çalması; gece ise gökyüzünün amber saçmaya başlaması, zümrüt denizinde altın geminin kaybolması gibi beliğ ifadelerle zikredilir:

Yine gökyüzi oldı canber-feşân

Kara tonın egnine aldı zaman (1034)

Çü başladı gökden güneş togmaga

Yine tahtı üstüne nûr agmaga (1261)

Çü Çîn kavmi Hindû çerisin sıdı

Kara zengî kâfûrla yüzin yudı (3214)

Kanat yaydı tâvus Kaf dan Kafa

Kara karganun boynı yidi kafa (3576)

Çü togdı güneş çevreyi tutdı nûr

Cihân geydi kâkum çıkardı samûr (2074)

Kahramanların ruh hâli ile zikredilen zaman arasında ilgi kurma gayretindeki müellifin geceye dair anlatımları çoğunlukla menfi değildir. Genellikle bilinmezliği ve karamsarlığı çağrıştıran gece, bu eserde kahramanların geceleri vuslata ermeleri sebebiyle keyifli anlara eşlik eden bir süreç olarak güzellikleri üzerinden vurgulanır. Ancak yaşanan olayların olumsuza dönmesiyle zamana bakış da farklılaşabilir. Aşk oyunlarıyla renklenen gece; ayrılık vakti olduğunda zifiri karanlık, yalnız ve kasvetli olur. Bu noktada zamanın göreceliliğine dair söylemler de dikkat çeker. Âşık, gecenin uzunluğunu bitmeyen bir y1l gibi algılar:

Geçen gice olmış durur ana yil

Tan atınca dinlenmedi eyle bil (1525)

Eserde zaman kesintisiz akmaz. Olayların kronolojik ilerleyişi çoğunlukla geriye gidişlerle kırılır. Bazen de zamanın düz, çizgisel akışı, kahramanların farklı zaman dilimlerinde yaşadıkları maceraların anlatımıyla bozulur. İç içe geçmiş bu ara hikâyeler, zamansal sıçramalara neden olur ve Süheyl ile Nevbahâr'in kavuşmalarıyla tekrar bir noktada birleşir. Art zaman denilen ve geri dönüşlerle oluşan ikinci zaman çizgileri mesnevide sıkça karşımıza çıkar.

\section{Mekân}

Çevre ve atmosfer şeklinde de ifade edilen mekân, olay örgüsünün gerçekleşeceği sahne olduğundan olayın akışına dair çeşitli ipuçlanı içerir. Bu nedenle kurgusal eserlerde mekânın tesadüfi seçilmesi söz konusu değildir. Genellikle önemli bir işlevi olan bu unsurun başlatıcı, bağlayıc1 ya da tamamlayıcı bir görevi vardır (Ayyıldız \& Birgören, 2014, s.79).

Süheyl ü Nevbahâr'da zaman gibi olayların yaşandığı mekân da kişisel yorumlara oldukça açıktır. Mekânlar, aşkın ve kahramanların kemale ermesi hususunda derin, sembolik değerlerle 
yüklü, farklı boyutlarla ele alınması gereken bir yapı unsuru olarak karşımıza çıkar. Eserde İç mekânlarda saadet dolu hadiseler yaşanırken dağ, deniz ve çöl gibi bilinçaltı çeşitli çağrışımlara açık dış mekânlarda ise ayrilık hâli söz konusudur. Örneğin; yolculuk esnasında karşısına bir çöl çıkan Nevbahâr, üç gün üç gece burada kalır. Sıcağa açlık ve susuzluğa rağmen korku içinde değildir; her an Süheyl’i düşünür. Bir noktada çöl, artık aşkın ve kahramanın tamamen kemale erdiği yere evrilir. Burada yaşananların ardından ruhsal yolculuğunu da tamamlayıp olgunluğa erişen kahraman, neredeyse ölmek üzereyken karşısına Tûfân adlı bir şehir çıkar. Bu şehirde büyük şenliklerle karşılanır. Tekâmüle ulaştıktan sonra cennet gibi bir yerde ümitsizlik ve kaygıdan uzaklaşıp saadete erer. Tüm zorlukları aştıktan sonraki ödül mekânı Tûfân'da, Nevbahâr sultan olmuştur. Çöl, bu anlatım biçiminde mücadele ile geçen dünya hayatını; şehir ise Cennet'i çağrıştırmaktadır. Saraylardan sonra çöl ve sahralara düşen kahramanın çölden sonra yeniden saraya dönüşü, hayatın iniş çıkışlarına da gönderme yapar. Acizlik ve iktidar, yokluk ve bolluk, yalnızlık ve şehrin tüm kalabalı̆̆1 gibi karşıtlıklar, bu mekân tasarımlarındaki dönüşümlerle somutlaştırılmış olur. Nevbahâr'ın hak ettiği değeri ve asıl kimliğini bulduğu Tûfân'da tahtın da temsili bir değeri vardır. Nevbahâr, kendi tekâmülünü tamamlayıp tahta çıkarak mutlak gücü temin ettiğinde tüm olayların ve kahramanların kontrolünü eline alacak, artık her şey onun istediği şekilde olacaktır.

Tûfân oldukça dinamik bir mekândır. Hem şehrin geçmişi hem de Nevbahâr'ın oraya gelmesinden sonraki olaylar, eserde dikkatleri bilhassa buraya çekmektedir. İlk gelen kişinin sultan olacağı, tüm kahramanların bir şekilde yollarının düştüğü bu mekân, eserin masalsı havasına katkı sunar; yoğun biçimde ilginç tesadüflere sahne olur. Mesnevinin sonunda ise, olayın düğümünün çözüleceği bir dekora dönüşür.

Mesnevideki kahramanların özellikle yolculukları esnasında karşılaştıkları mekânlar, ruh hâllerinin ve kişiliklerinin şekillenmesini sağlamıştır. Nevbahâr'ın evden ayrıldıktan sonra yalnız olmayı planlamadığı yollarda yaşadığı zorluklar önce pişmanlıkla neticelenir. Yol, başlangıçta iç hesaplaşmaların ve tehlikelerin mekânıdır. Ancak sonrasında, farklı mekânlarda kahraman mücadeleye adapte olur; cesaret ve özgüvenini artar. Hem Süheyl'in hem de Nevbahâr'ın yalnız kaldığı mekânlar, kişiliklerindeki ve duygularındaki devinim ve gelişimi hızlanır.

Eserde, kilitli kapıların ardındaki gizemli alanlar, heyecan verici olayların başlangıcını tetikler. Süheyl ve Nevbahâr'ın ikinci kavuşmalarına kadarki ayrılık sürecinde mekânlar sürekli değişir. Değişen bu yeni mekânlar da yeni maceralara, gizemlere zemin hazırlar. Özellikle Nevbahâr'ın yolculuğu esnasında karşılaştığı yerlerle ilgili anlatımlar, ilgiyi sürekli canlı tutar. Müellif, zaman zaman oluşan durağanlığı, onun bulunduğu olağan mekânlardaki olağanüstü unsurların gizemi ile dağıtmayı başarır.

Olayların verdiği gerçeklik hissine katkı sunan gerçek/çi mekânlar; Çin ve Yemen gibi ülkelerin dışında saray, bahçe, savaş alanları, gemiler ve köşklerdir. Olağanüstü olaylar dahi bahçe, deniz kenarı, orman gibi yerlerde hâsıl olur. Mesnevide ülke ve şehir isimleri tam olarak belirtilir, muğlak bırakılmaz. Bazen de mübalağalı ayrıntılar ve muhayyel zamanlarla sunulan, kale gibi gerçekçi mekânların, hayali bir mekân tasavvuru oluşturması söz konusu olur:

Kyyâs eyle işbu kadar iy cazîz

Ki yidi gök anun ileydi sekiz

Tamında kişi yüriseydi yaya

Bükideydi kim göge tohunmaya

İnen burc1 sarp u kapusı demür

Yöresi derin handak içi çamur (4192-4194) 


\section{Dil ve Anlatım}

Ne anlatıldığından ziyade nasıl anlatıldı̆̆ının önemli olduğu klasik eserlerde dil, tüm edebi metinlerde olduğu gibi, temel anlatım aracıdır. Müellifin sanat kaygısı ve tercih ettiği anlatım biçimi, dil tasarruflarını şekillendirir. Buna karşın dilin kahramanların özelliklerine uygun seçimi, klasik dönem sanatçısı için bir zorunluluk teşkil etmez. Genel olarak mesnevilerdeki kahramanlar eğitimi, yaşı, sosyal statüsü ne olursa olsun benzer sözcüklerle konuşturulur; özel jargonlar tercih edilmez. Söz konusu bu husus, Süheyl ü Nevbahâr'da da dikkat çekmektedir.

Mesnevide zaman zaman hissedilen biçim ve sanat kaygısının ötesinde, okura mesaj verme isteği her daim ön plana çıkar. Eserde malumat-füruş anlatıcı, müellifin misyonunun temsilcisi olarak varllğıını her daim hissettirir. Mesnevideki bütünsel bakış açısı, müellifin dünya görüşüne göre şekillenirken olaylar da verilmek istenen mesajlara göre düzenlemiş gibi görünür. Yılmaz’ın (1997) roman yazarı için "Romancı, olaylar karşısında tarafsız değildir. O, iyilerden ve iyiliklerden yanadır; kötü ve kötülüklere karşıdır. Kötülüğü sergilerken bundan bir ibret dersi alınmasını istemektedir." (s. 46) diyerek anlatılarda dikkat çektiği didaktik amaçlar, Süheyl ü Nevbahâr'da oldukça belirgin bir görünüm kazanmaktadır. Mesnevide çoğu zaman mesajın kitlelere ulaşabilmesi için sanatın bir araç olduğu fikri hasıl olur. Düşünsel bir eser fonksiyonu ile karşımıza çıkan mesnevinin dil ve anlatım özellikleri de genellikle bir görüşü benimsetmeye yönelik şekillenir. Neredeyse tüm imaj ve kavramlara sinen idealler, savunulan fikirler oldukça açı biçimde verilmesine rağmen anlatıcı yeniden detaylı açıklamalar ve yorumlarla mesajın altını tekrar ve tekrar çizmeye gayret gösterir. Böylece metnin kurmaca havasindan uzaklaşmak oldukça güçleşir:

Anun andı sinmaya sinün sözün

Dahı yigregin anlar ola özün

Sımah andı gelmez kişiye eyü

Ya irkege yâ hoz dişiye eyü (1318-1319)

Sarâya muvâfik yarar konş1

Öyinde gözetmek gerek konuşı

Gerek kişi konşı bula andan ev

Gerek kimse yoldaş düze andan av (1337-1338)

Kifâyetlü âdem gerek her işi

Düze öndin ü sonra bize kişi

Ana vaktı vü fursatı gözleye

Ne kim sırrı var açmaya gizleye

Kişi sabr ile bulur işe zafer

İveceklik idende kalmaya fer (1577-1578-1579)

Hoca Mesud'un düşünce yapısının, hayat tecrübelerinin, olaylara bakış açısının ve dünya görüşünün aktarıcıları bazen de kahramanlar olur:

Tenüm hasta gönlüm gidüpdür bugün

Beni cışk gör kim nidüpdür bugün

Kaza ugradı bana elden saça

Kazadan kişi kankı yana kaça (750-751) 
Müellif, bazen de olayları başkasından duymuş gibi anlatır. Burada -miş'li geçmiş zamanın kullanımı ile eserin masalsı havası belirginleşir.

Sudan gitmemiş irteye dek gözi

Görine diyüp Nev-bahâr'un yüzi

Süheyl'ün dilegi tamâm olmamış

Tam üstine ol umdug1 gelmemiş

Tana dek figân eylemiș zâr zâr

Ne yatup uyumış ne tutmış karâr (1372-1373-1374)

Eserin sunduğu düşünsel önermeler olan cömertlik, vefa, yardımseverlik gibi erdemleri ve ahlakı anlatırken nasihat veren müellif, olay ve kişilere yönelik kanaatlerini telkin ederken doğrudan okura karşısındaymış gibi hitap eder. Süheyl ü Nevbahâr'da müellifin okuru ile sohbet eder gibi yazması, samimi ifadeleri, halk hikâyelerindeki anlatıcılarda olduğu gibi canlı bir performans izliyormuş hissi uyandırır. Müellif, bir meddah tavrıyla karşısındakilere sorular sorar; emir cümleleri kullanır:

Anı gör şunun bigi yire gelüp

Yoh ayah ki başın eline alup

Degül mi aceb gör neler işler ol

Nite başarur şunca sarp işler ol (2328-2329)

Çü dördinci gün oldı bunlar gider

Süheyl-i Yemen gör ne dir ü nider (846)

Müellif, anlatımını sık sık kesintiye uğratır. Bazen araya girip verdiği öğütler, bilinen bir hikâyenin tekrar tekrar sunumu olan geri dönüşler bazen de âşıkların dilinden söylediği şïrlerle kesilen anlatımların ardından:

Yine biz Süheyl ile kızdan haber

Diyelüm ki niddiler iy pür-hüner (1999)

diyerek asıl konuya döner. Eserde okurla sohbet havasındaki bu samimi ifadeler, kahramanların yaptıklarını izah eden söylemlerde de devam eder.

Hoca Mesud'un dini görüşler etrafinda şekillenen ve tasavvuftan beslenen inanç-düşünüş sistemi, sanat zevki, dünyayı algılama biçimi eserde belirgindir. Mesnevideki tasavvufí anlatımlar, oldukça derinlerinden sezdirilmekte; özellikle tecelli fikrinin tezahürü olan ifadelere sıklıkla yer verilmektedir. Örneğin; mesnevinin leitmotivlerinden biri olan Nevbahâr'ın resminin yansıdığ1 havuz; eşsiz güzelliğin ayna misali aksettiği yeryüzü olarak düşünülebilecek, tasavvufi çağrışımlara açık bir imgedir. Nitekim Hak âşıkları da maşuğun kendisini değil tecellilerini görüp bu mutlak güzelliğin yansımalarına meftun olmuştur. Buradaki temsillerle verilen tasavvufî anlamlar, hikâyenin bir bölümünde Nevbahâr'ın resmini gören sıradan kissilerin onu fark etmediği; ancak bu resme gönül gözüyle bakanların onun gerçek manasını idrak ettiği şeklindeki söylemlerle desteklenir:

Bakan kişiler rengin anlar hemîn

Görür sûreti hûb tanlar hemîn

Ne bilür ki anda ne manî ola

Eger bile sûretde nite kala 
Olur sûretün zâhiri halk içün

Velî bâtınî manîsi Hakk içün (3730-3732)

Görüp sûreti ol kişi tanlaya

Ki sûretde manî yönin anlaya (3740)

Bir başka bölümde ise, Nevbahâr'ın gördüğü denizden çıkan yırtıcı hayvanlar anlatılırken sözü inandırıcı kılmak için, Allah'ın kudret ve hikmetine yönelik dini söylemler ön plana çıarılır:

Nite kim kuruda olur cânavar

Denizde dahı hem anun bigi var

Zihi kâdir ü hikmet issi Çalap

Ki her birine ol virür rrzkı hep (2945-2946)

Ben ü yâ benüm bigi yüz bin kişi

Çalap buyrugınsuz başarmaz işi

İnâyet k1lası olıcak birez

Kamu müşkil işler düzilür genez (1423-1424)

Müellifin inanç sistemi kadar mizac1, psikolojisi, dönemin zihniyeti de metnin yapısı ve anlatım tarzı üzerinde etkili olmaktadır. Bu bağlamda mesnevide, anlattıklarının çıkarsamalarını okura bırakmayan, okur adına düşünüp onu yönlendiren müellif; olayı da kahramanlarını da kendisinin ve döneminin bakış açısını somutlaştırma aracına çevirir. Okurda oluşması beklenen duygular, öfke veya sempati; müellifin kontrolüne geçer ve çağının beklentilerine uygun olan mutlak doğrularla yönlendirmeler yapılır.

\section{Anlatım Teknikleri}

\section{Tasvir}

Süheyl ü Nevbahâr'da tasvirler, realist ve çoğunlukla detaylandırılmış bir görünüm arz eder. Bilhassa başkahramanların ruhsal ve fiziksel portreleri çizilirken yapılan tasvirler oldukça başarılıdır. Müellif, kahramanlar dışında, olayların yaşandığı mekân ve bu mekânların verdiği hissiyatı da başarıyla aktarır. Böylece canlı ve çok yönlü bir anlatım sağlar. Özellikle Nevbahâr'ın ilk kez görüldüğü kapalı kapılar ardındaki bahçe, yaşadığ1 köşk, tahta çıtığ1 Tûfân şehrinde yaptırdığı mimari eserler gibi Nevbahâr'a dair mekânların tasvirlerine eserde geniş bir yer ayrılır. Sevgilinin bulunduğu bu mekânlar, divan şiirindeki geleneksel anlatıma paralel olarak duyguların yoğunlaştığı, renkli ve gönle hoş gelen, sübjektif anlatımlara açık alanlar olarak ön plandadır. Mekân tasvirlerinde dikkat çeken bir başka husus ise, yoğun biçimde Cennet'e yapılan atıf ve teşbihlerdir:

Bezenmiş yeşil kızıl u agıla

Ber-â-berlik iderdi uçmagila (487)

Hem eyle itdiler kim dinmiş idi

Yemen içi uçmaga dönmiş idi (5572)

Tasvirler olay akışında kopmalara neden olmayacak şekilde anlatımın başlangıcında yer alır. Böylece anlatım ve heyecan sekteye uğratılmaz. Bu tasvirler, durum, mekân veya kahramanın zihinde canlandırılmasına imkân sunacak şekilde ve yeterli uzunlukta tutulur. Ancak kahramanların özellikle eylemlerini veya içinde bulundukları durumları anbean sahneleyen tasvirlerde müellif, gereksiz ayrıntılar, iç monologlar ve yorumları ile anlatımını bazen gerekenden uzun tutar. 
Tasvirlerde zaman zaman mübalağalı anlatımlar dikkat çeker. Özellikle mesnevinin leitmotivlerinden olan ziyafet sofralarının büyüklüğü ve ihtişamı oldukça abartılı tasvir edilmektedir. Ziyafetler düzenlemek güç, iyilik, dostluk ve cömertlik göstergesi olarak eserde önemli yer tutar. Süheyl, kurdurduğu sofralar ve dağıttığ1 hediyelerle gönülleri fetheden bir kahramandır. Sofra, Süheyl ü Nevbahâr'da güç, cömertlik ve dostluğun sembolü olarak oldukça önemli bir konumdadır ve şöyle tasvir edilir:

Şu denlü dökilür honı iki mîl

Gelür bişe önüne önüne bil

Yidiler ü götürdiler hâs u câm

Dahı toptolu yazı yüzi tacâm (1151-1152)

Piyâle virür la’l ü altun geyik

Bir ulu gümiş pîl dururdı dik

Kiz1l altun aslan murassa ulu

Kamusınun içi süciler tolu (1154-1155)

\section{Diyalog}

Diyalog, kahramanların duygu ve düşünce dünyalarının aracısız şekilde aktarılmasına imkân veren bir anlatım tekniğidir. Süheyl ü Nevbahâr'da olay, çoğunlukla diyaloglar aracıllğıyla aktarılmışır. Diyaloglarla, kahramanın geçmişi, geleceği veya o anki ruh hâli bildirilir. Bazen de müellif, eserde yalnızca yaşananları değil; gelecekte yaşanacakları da kahramanların diyalogları esnasinda aktarıp olayları hızlandırır:

Atam urisar şöyle tedbîr ü rây

Ki yoh gitmegil bunda durgil bir ay

Cevâbın girü eyle viribigil

Ki turımazam yavlag oldum hacîl

Son ucı biş on güne râzî ola

Zihî maslahatc1 ki kâzî ola (2066-2068)

Eserde diyalogların yoğun olduğu bölümler, yapılan yorum ve açıklamalar ile varlığını her an hissettiren anlatıcıyı nispeten silik hâle getirmektedir. Yani diyaloglar, anlatıcıyı devreden çıkarırken okur, bir tiyatro oyunundaki gibi, ön planda kahramanların olduğu, gösterme tekniğinin kullanıldığı bir metinle baş başa kalır. Olayların aracısız aktarılması ise, bir yandan kahramanlar arasındaki çatışmayı belirginleştirir; diğer yandan okuyucunun dikkatini tamamen metne çeker. Müellifin dilinden değil, kahramanlardan olayları öğrenen okur, anlatımın akıcılığına kapılır. Ayrıca eserde çeşitli sebeplerle sık sık sekteye uğratılan akış, gerçekçi diyaloglar ile yeniden temin edilir.

Süheyl ü Nevbahâr'daki saz eşliğindeki karşllıklı konuşmalar, eğlenceli ve samimi bir ifade ile aktarılan atışmalar, eserin hem duygulu hem de en renkli bölümleri arasındadır:

Kabûl idüp uyımadun bu gice

$\mathrm{Bu}$ özri nitesi dileyem nice

Cevâb eyle virdi yüzini göre

Berü ag ne söz vaktidür iy sere (1740-1741)

Degülven kuş u uçmaga yaramaz

Girü dönüben kaçmaga yaramaz 
Buyurdun sözün simadum geldüm uş

Elüm irmedügin sana bildüm uş (1745-1746)

Didi hey ne söylersin eyleme lâg

Ki dîvârun ardında olur kulag

Kiși sizmedin saçum ucını tut

Niçe bir diyeven işitgil öğüt (1754-1755)

\section{3. İç Monolog}

İç monolog tekniği Süheyl ü Nevbahâr'da oldukça yoğun biçimde kullanılmaktadır. Müellif; iç monologlarda kahramanların içinden geçenleri, kendi kendilerine düşündüklerini, duygularını ve geleceğe dair planlarını belirtip sanki bunları sesli olarak ifade ediyorlarmış gibi cümlelerin sonuna "didi" ifadesini ekler. Bazen de "bunu düşünüp" diyerek söylenilenlerin kahramanın iç sesi olduğunu belirtir:

Süheyl-i Yemen bu sirı tanladı

Didi kim atam bunda ne anladı (460)

Togan bir ulu pâdişâhdur bayık

Ki göre beni kendüzine lâyık (875)

Öginde didi bu yigit gördügi

Kime kim ire gönlini virdügi (1126)

Bu kez key bakıcah kızı yüzine

İçin söyledi kendü kendüzine

Ki işbu hakîkat kızumdur benüm

Bu derde hemîn ol ola dermânum

Ki bir göreyim bunı söyledeyim

Bilem iş nedür bârî soyladayım (2241-2243)

\section{Geriye dönüş}

Süheyl ü Nevbahâr'da çok sık yer verilen geriye dönüş, hemen her kahramanın hikâyesinin anlatımı esnasında kullanılan bir tekniktir. Okur, bu teknikle geçmişte bir gezintiye çıkarılır ve kahramanların hikâyelerini onların kendi dilinden duymuş olur. Ancak hâlihazırda bilinen, bu hikâyelerin tekrarında yeni bir olay veya kahramanların öznel değerlendirmeleri bulunmaz. Bu sebeple de geriye dönüşlerle anlatılan olaylar, daha önce anlatılanların gereksiz yinelemelerine dönüşürken anlatılanlar yeknesak bir hâl alır. Hoca Mesud, bu tekniği ara ara mesnevideki bir şiirin içinde sunar:

Zevk u îş ü ili güni vü temâşâ kılmag1

Kamusın girü kodum uş ileri tutdum sefer

Râhatı zahmetlere tatluyı acı dirlige

Degşürüp yürürvenin kim yârdan bilem haber (1368-1368)

Ben ü dahı birkaç ulular kızı

Şol ohtın ki uyıdı deniz yüzi

Gemiye girüp gezdüm içdüm yidüm

İrişdi gice vü birez uyıdum 
Ki çengün âvâzı dimâgumı ter

İdüpdi perîler ulusı meğer

$\mathrm{Ol}$ arada hâzır bulınur kapar

Su altına iltür gemiden sapar

Anı bilürem çünki uyanuram

$\mathrm{Su}$ altındayiken oda yanuram

Ki başumda otururdı işbu perî

Ki gördün yigitdür degüldür karı

Ne çâre gerek bile hoş dirilem

Katından yaramaz eger irllam

Benüm bu senün ser-güzeştün nedür

Kazıyye ki sen bunda düşdün nedür (3489-3496)

\section{5. Özetleme}

Özetleme, Süheyl ü Nevbâr'da genellikle geriye dönüşler esnasında kullanılan bir tekniktir. Eserde müellif, kahramanların başlarından geçenleri özetleyerek birbirlerine aktarmaları yoluyla bu iki tekniğe birlikte yer vermiştir. Aşağıda, Nevbahâr'ın daha önce dadısına detaylı şekilde anlattığı rüyasının, özetleme tekniği kullanılarak tekrarlandığı bir bölüm alıntılanmıştır:

Ki görmiş idi düşde hem Nev-bahâr

Togan olubanın havâya agar

Bir atlu yazı yirde anı görür

Okır çagırur bir arada turur

İşidür ünini havâdan iner

$\mathrm{Ol}$ atlu yigidün eline konar

Çü bir lahža oturur andan uçar

Bu yigit elinden yabâna kaçar (1119-1122)

\section{Bakış Açısı}

Bakış açısı hususunu Şerif Aktaş (2005) şöyle ifade eder: "Bakış açısı, anlatma esasına bağlı metinlerde vaka zincirlerinin ve bu zincirin meydana gelmesinde kullanılan mekân, zaman, şahıs kadrosu gibi unsurların kim tarafindan görüldüğü, idrak edildiği ve kim tarafindan kime nakledilmekte olduğu sorularına verilen cevaptan başka bir şey değildir.” (s. 78). Bakış açısı; olay, zaman, kişi ve mekânın kim tarafindan görüldügüu, anlaşıldığı kim tarafindan nakledildiğine dayanır. Müellif, anlatmak istediklerine uygun olarak bir anlatıcı kurgular. Müellifin değil, anlatıcının bakış açısına göre algılanan varlığın tezahürleri de bakış açısının verdiği imkânlarla şekil alır. Eserde tercih edilen bakış açısıyla olay zincirinin şekli, başlangıç ve bitişi, şahısların tanıtımı, kurgusu, seçilen mekân ve tasvirinin sunumu çeşitli değişimler gösterir. Bu nedenle, eserle alakalı özellikleri açıklamak ve yorumlamak için bakış açısını tespit etmek önemlidir. Aksi hâlde eserin dünyasına tam olarak nüfuz edilmesi güç olacaktır (Aktaş, 2005, s. 77-78).

Anlatıcı, okurla müellif arasındaki kurmaca kişidir. Kurgusal metinlerde müellif, anlatıcı kimliği ile konuşur. Anlatıcı bazen müellifin gölgesidir, bazen de müellifin üstünde ondan daha iyi bilen, sezen ve gören bir unsur olarak karşımıza çıkar. $O$, ya bir kahraman hüviyetinde ya olayları sessizce uzaktan gözlemleyen ya da her şeyi bilen ve gören biri olarak belirir. Bu anlatıcının dili ve 
dikkati ile anlatılan zaman, mekân, olay; anlatıcının onu idrak şekline göre şekillenir (Aktaş, 2005, s. 50).

Süheyl ü Nevbahâr'da hâkim anlatıcı bakış açısı kullanılmıştır. Hâkim bakış açısıyla olayları anlatan kurgusal âleme ait anlatıcı, zaman ve mekânla sınırlı değildir. O, kahramanların zihinlerinden geçenleri, neler yaptıklarını önceden konuştuklarını bilen ve gören kişidir. Anlatıcı, ayrıntıları fark edip iç konuşmaları duyar. Sınırsız bir güce sahiptir. Bu noktada hâkim bakış açısı ile anlatım, anlatıcının ölüm sonrasına dair bilgileri dahi anlatma imkânını verir. Kahramanların rüyalarını, zihinlerinden geçenleri bilen anlatıcı, özellikle ruh hâllerinin anlatımı esnasında bu bakış açısını kullanarak akışı düzenler, gerçekçiliği/inandırıcılığı temin eder.

Öginde buyıdı ki ben dün gice

Niçün gitdüm ugradum öküş güce (1862)

Öginde geçen Nev-bahârun aceb

Dönüp söylemedügi neyki sebeb

Meger andan ötrü ki eglendüm uş

Bana küsdi vü olmadı gönli hoş

Ger eglendüm ise ahı noldıdı

Günâh andan artuk dahı noldıdı (2400-2402)

Oturdug1 yirde Süheyl-i Yemen

Şunun bigi kim ayı tuta tuman

Kara kaygu gönlini basdıyıdı

Sinuhlu olup katı busdiyidı (2250-2251)

Ancak her şeyi bilen bu anlatıcı, eserin bir yerinde şaşırtmak için, kahramanın söyleyeceklerinin yalan mı doğru mu olduğunu bilmediğinden bahsedebilir:

Hikâyet bolup göyner uş özümüz

Yalan mı ya girçek ki yok sözümüz (2030)

\section{Söz Sanatları}

Süheyl ü Nevbahâr'da sik sik beliğ ifadelere yer veren Hoca Mesud, söz sanatlarıyla sağlanan özlü ve güçlü anlamlarla metne şiirsel bir ahenk ve estetik değer kazandırmayı başarır. Mesnevide en sık rastlanılan söz sanatları iktibas ve leff ü neşr ve mübalağadır.

İktibas; roman literatüründe bir anlatım tekniği olarak montaj adıyla yer alır ve atasözü, ayet, hadis, vecize gibi bilinen bir sözü, esere aktarma demektir (Köksal, 2005, s. 44) Didaktik yönü olan metinlerde vazgeçilmez söz sanatlarından olan iktibas, Süheyl ü Nevbahâr'da da en çok kullanılan sanat olarak karşımıza çıkar. Müellif, bu sanatla bir taraftan anlattıklarını daha anlaşı1ır kılarken diğer taraftan da sözlerini desteklemeyi amaçlar.

Kamu cânluya sevgülüdür canı

Kitâbında Firdevsî hûb dir bunı

Meyâzâr mûrî ki dâne keşest

Ki ü nîz cân dâred ü cân hoşest (2957-2958)

Gidenün yolin kimsene baglamaz

Meseldür ki kendü düşen ağlamaz (736) 
Meseldür kişi eydür ulu kiçi

Olur başa bun gelse başmahc1 (1963)

Türkçe bir atasözünün montajı bazen Farsça yapıllırken bazen de müellif, yer verdiği vecizenin söyleyenini zikreder:

Meseldür ki tündî neyâyed be-kâr

Be-nermî ber-âyed zi-sürâh mâr (2707)

Eserde özellikle Süheyl ile ilgili anlatımlarda çokça mübalağa sanatına başvurulmaktadır. Süheyl için yapılan sarayın on gün gibi bir sürede tamamlanması, savaş esnasındaki gücü, kurdurduğu sofralarda pişirilen etlerden yerin görünmeyecek hâle gelmesi, ikramlarının çeşitliliği, ziyafet için kestirdiği hayvanların sayısı gibi birçok durumla ilgili mübalağalar oldukça yoğundur:

Yüce köşk âlî sarâylar düzer

Niçe kişinün anda gücin üzer

Dahı bir eyü bâg taht urmaga

Ki baka dura oturan 1rmaga

On on iki günde düzer bir sarây

Ki şâh girse içine olur gedây (1341-1343)

Şu denlü sıgır u koyun kırdılar

Ki dükenleyüp son ucı gördiler

Yir altında kurtuldıdı bir öküz

Kuzı gökde bir kim Hameldür henüz

Binerlik semiz yunt binden öküş

Uçarda ne kim eti yinürse kuş (2110-2112)

Nevbahâr'ın resmini yapması için çağrılan nakkaşın ve eserde söz konusu edilen diğer ustaların hünerleri de mübalağalı biçimde şöyle anlatılır:

Bulıvirdi bir koca ustâ nakâş

Ki güneş yüzine düze göz ü kaş

Yazar ise sî-murg1 dîvâra ol

Dîvâr uça Kâf tagina duta yol

Bir iki dem içinde kim reng eze

Diler ise biş on şehen-şeh düze (3658-3659-3660)

Zikredilen söz sanatları dışında teşbih, leff ü neşr ve cinas (cinas-1 nakıs) da mesnevide yer alan diğer sanatlardır:

Elinde surâhî ile câm idi

Yolında ne müşkil ser-encâm idi (2323)

Niceme dürişürse illâsı var

Nite güneşi balçıgıla sıvar (2325)

\section{Sonuç}

Mesneviler, yine tahkiye esasına dayalı roman ve hikâyeler ile olayın zaman, mekân ve kişilere bağlı olarak anlatımı, kullanılan bakış açıları, anlatım teknikleri gibi birçok yönden 
benzerlikler arz eder. Bu noktada, Süheyl ü Nevbahâr mesnevisi modern anlatı türleri inceleme yöntemleriyle tahlil edilmiş, aşağıdaki sonuçlara varılmıştır:

1. Süheyl ü Nevbahâr; yer yer oldukça özgün, sürükleyici, merak uyandıran, bir kurguya sahiptir. Tasvirlerin ve ruh tahlillerinin sinırlı olduğu eserde müellif; temel kurguyu aşk, yolculuk, eğlence, cömertlik, mücadele, akıl oyunları üzerine kurar. Mesnevide işlenen olay, Süheyl'in Nevbahâr'a âşık olması neticesinde ona kavuşmak için çıktığ yolculuk ve zorlu mücadelelerin sonunda kahramanların birbirlerine kavuşmalarıdır. Gerilim niteliği taşıyan bu olayların çatışma zeminini aşk ve ayrılık oluşturmaktadır. Aşk, sadakat, vefa ve cömertlik gibi temaların işlendiği eserde anlatımlar, nesneler ve kişilerden ziyade, genellikle ahlaki yönü olan soyut kavramlar üzerine inşa edilmiştir.

2. Mesnevide kahramanların genellikle karakteriyle uyumlu, tahmin edilebilir eylemler gerçekleştirdiği görülür. Kahramanlar, manevi tarafları veya ruhsal yapılarından çok eylemleri ile ön plana çıkarılır. Onlar ya iyi ya da kötüdür. Ancak, bu düz karakterli şaşırtmayan kahramanlar, bazen kararsız ve değişime açık bir kişilik sergiler. Okur, gelgitler yaşayan kahramanların bir sonraki adımını kolayca tahmin edemez. Buradaki belirsizlik, bir heyecan unsuruna dönüşür.

3. Süheyl ü Nevbahâr'da zengin kahraman kadrosu dışında, özellikle zamanın işlenişi önem arz eder. Eserde zaman bildiren ifadelere çok sık yer verilir. Zamansal değişimler net biçimde hissettirilir. Zaman anlatımlarının sanatsal işlevi, art zamanlı bir akış ve özellikle gecenin önemli bir unsur olarak ön plana çıkarılması dikkat çeker.

4. Mesnevide mekânlar, olaylar ve kişiler gibi çoğunlukla gerçekçidir. Gerçekdışı, masalsı unsurların yer aldığı bölümler ise her ne kadar şaşırtıcı ve dikkat çekici olsa da maceranın içinde önemli bir yer teşkil etmez. Süheyl ü Nevbahâr'da daha çok diş mekânlardan söz edilmektedir. Bunun nedeni, olayların genellikle yolculuklarda yaşananlar üzerine kurgulanmış olmasıdır. Ayrıca eserde mekânın anlatımı, zaman zaman kahramanların psikolojisi ve yaşanan anın hissettirdikleri ile bağlantılı olarak sunulmaktadır.

5. Mesnevinin bütünsel bakış açısı hem müellifin dünya görüşüne hem de okurun beklentisine göre şekillenmiştir. Müellif kendine özgü zevkleri, prensipleri, algılama biçimlerini anlatırken olay, zaman, mekân ve kişilerin birer araca dönüştüğü hissini verir. Dilsel tasarrufları, söyleyiş biçimi ve anlatım teknikleri yönüyle müellif, döneminin beklentilerinin ötesine geçemez. Dini ve tasavvufi açılımların yoğun olduğu XIV. yüzyılda yazılmıs bu eser hem çağının hem de müellifin felsefesine dair izler taşır.

6. Süheyl ü Nevbahâr'da yapısal unsurlar kadar, anlatıcının amacı hususu da kurguya yön verme özelliğiyle ön plana çlkmaktadır. Eserde olaylara mesafesi sübjektif şekillenen, kahramanlarını yargılayıp değerlendiren anlatıcı, okurun kendi çıkarımlarına imkân vermez. Okura benimsetmek istediği şahsi görüşleriyle tüm doğru-yanlış, iyi kötü sınırlarını belirler; anlattıklarından çıkarılması gereken sonuçları söyler. Okurun yerine metni yorumlar ve ne düşünülmesi gerektiğine karar verir. Okuru bilgilendirmek, bir görüşü benimsetmek üzere dikkatler uzun bir süre için olay ve kahramanlardan uzaklaştırılır. Müellifin kimliğini ve yorumlarını esere katması ise hikâyenin dünyasına tam olarak girilmesini zorlaştırır. Metnin amacı, konu sınırlarını aşar. Eserdeki bu didaktik, topluma bilinçli ve iradi biçim verme çabasının ürünü anlatımlarla hayatın gerçekleri arasındaki mesafenin oldukça açılmış olması da dikkat çeker. Aktarılan deneyim ve dünya görüşü müellifin ütopik âlem tasarısının dışavurumu olur.

7. Tahkiyeye dayalı geleneksel eserlerde olduğu gibi Süheyl ü Nevbahâr'da da en çok kullanılan teknik anlatmadır. Anlatma dışında tasvir, geriye dönüş, özetleme, diyalog ve iç monolog tekniklerinin kullanıldığı mesnevi, anlatım tekniklerinin uygulanması noktasında zengin ve başarılıdır. Konunun akışını her firsatta kesip okuru didaktik bir anlatımın içine sürükleyen müellif, kahramanı aracıllğıyla veya bizzat kendisi mesajlar verir, olayları aktarır, tasvirler yapar. Ancak, tiyatroda olduğu gibi, anlatıcının aradan çekilip olayı diyaloglar ve iç monologla 
kahramanlarına anlattırmayı tercih ettiği de görülür. Özellikle uzun diyaloglar, okuyucunun olayları bir nevi müşahede etmesini sağlamaktadır. Bu noktada özetleme ve geriye dönüş teknikleri de müellifin eserdeki varlığını kısmen ortadan kaldıran teknikler olarak işlev kazanır.

8. Sanatçının gücü, kurgunun estetiği ve okuru içine çeken yönleriyle doğru orantılıdır. Bu hususlarda oldukça başarılı kabul edebileceğimiz eser, olayın kurgulanması noktasında zayıftır. Örneğin; Süheyl ü Nevbahâr'da müellif, karşıt bir güç ortaya koymak isterken başarıyı yakalayamaz. Çatışmaya zemin hazırlayan durumları tam olarak kurgulamadığ1 için okur, kahramanların sebepsiz mücadelelerine, uzaklaşmalarına, kaçıp kovalamalarına şahitlik eder. Dolayısıyla çoğu yerde esas entrika unsurları, mesnetsiz inşa edilmiş gibi görünür. Süheyl ü Nevbahâr'da ara ara karşımıza çıkan tutarsızlıklar, abartılar, açıklanamayan tesadüflerin sıklığ1 veya müellifin kendi dünya görüşünü yansıtma isteğiyle okuru tabi tuttuğu sayfalarca konu dışı anlatım da yine kurgunun zayıf yönleri arasında yer alır.

9. Kafiye ve veznin sınırlayıcıllğına hatta bizzat müellifin de belirttiği gibi Türkçenin sınırlı imkânlarına rağmen, eserin canlı ve okuru içine çeken bir yapısı vardır. Mesnevi nazım türünün hususiyetleri gereği redif ve kafiyenin değişimi, ses düzeninin yenilenmesini; dolayısıyla metinde ahengi ve vurguyu temin eder. Şiir vasitasıyla hikâye anlatmanın olumlu ve olumsuz tarafları eserde bir araya gelir.

\section{Kaynakça}

Aktaş, Ş. (2005). Roman sanatı ve roman incelemesine giriş. Akçağ Yayınları.

Ayyıldız, M. \& Birgören, H. (2014). Edebiyat bilgi ve kuramları. Akçă̆ Yayınları. Yayınları.

Dilçin, C. (1991). Süheyl ü Nev-bahâr inceleme-metin-söəlük. Atatürk Kültür Merkezi

Köksal, F. (2005). Klasik Türk şiiri araştırmaları. Akçağ Yayınları.

Lukacs, G. (2007). Roman kuramı (C. Soydemir, Çev.). Metis Yayınları.

Stevıck, P. (2004). Roman teorisi (S. Kantarcıŏlu, Çev.). Akçağ Yayınları.

Tosunoğlu M. \& Melanlıoğlu D. (2005). Süheyl ü Nev-bahâr'ın Türkçe söz varlığ1 ve Anadolu ağızları. Türk Dili Araştırmalarn Yilliğg-Belleten, 53(1), 189-200.

Yılmaz, D. (1997). Roman kavramı ve Türk romanımn doğuşu. Akçağ Yayınları. 